\title{
Standing by the promise: Acts of anticipation in Rio and Jakarta
}

EPD: Society and Space 202I, Vol. 39(4) 573-589

(C) The Author(s) 2021

Article reuse guidelines: sagepub.com/journals-permissions DOI: $10.1177 / 0263775820982997$ journals.sagepub.com/home/epd

@SAGE

\author{
Laura Kemmer $\mathbb{D}$ \\ Humboldt-Universität zu Berlin, Germany
}

\section{AbdouMaliq Simone}

The University of Sheffield, UK

\begin{abstract}
Cities are promising machines always holding out prospects for better lives, always attempting to guarantee that things will not remain the same and that whatever changes do ensue are for the better. We propose a notion of "promise" not as simply another descriptor in a long line of adjectives about the city. Rather, we argue that the urban institutional landscape constantly generates new promises as way of anticipation, which in turn allows residents to write themselves into select urban operations. This article engages two central districts in Rio de Janeiro and Jakarta to explore how residents "stand by" the promise, not of passive waiting, but as maneuvers of either staying tuned to or as way of tactical detachment from the multiple trajectories which have been conjured up in the here and now. We understand these maneuvers as acts of "minor" future making that rely upon practices and materials that may seem of little use, but which enable a process of incremental small adjustments and collective subversion of urban trajectories of the transitory.
\end{abstract}

\section{Keywords}

Urban promises, anticipation, minor futures, detachment, standby, majority districts

\section{Introduction}

People bring to cities a multitude of aspirations that range from minimal survival to outlandish get-rich schemes. Cities are imbued with promises for the future to which no one cannot be simply indifferent. It is in this sense that we understand cities as promising 
machines, always holding out prospects for better lives, always attempting to guarantee that things will not remain the same and that whatever changes do ensue are for the better. Promises, here, are acts of anticipation in that they allow for making the future "into something that can be declared in advance of its arrival" (Ahmed, 2010: 29). In the intersection of so many walks of life, any enrollment of residents in the semblance of a collective common project requires that individuals and households are able to write themselves into some selection of these promises, as a way to orient what they pay attention to, how they will focus their time and resources. While delivery upon anticipated gains is seldom immediate, residents glean the institutional landscape of cities for at the least indications of a future delivery.

Urban promises are one expression of how cities channel desire; they haunt us with the expectation of something favorable to come. When the city promises, this is more than a being-promising or a declaration of something that "comes to us." Rather, urban promises are actively generated by momentary assemblages of institutions, authorities, and materialities that anticipate, sense, and divine the city-to-come (Färber, 2019). The promise exists as a form that holds these collectivities together (Kemmer, Forthcoming). If the city is a "machine" overcoding semiotic flows and territories and organizing desire in all its forms (Deleuze and Guattari, 1977 [1972]: 165), what kind of promises stand out, or does it really matter what is promised as long as something is promised?

It is from these considerations that we propose "promise" as a new way for urban studies to engage with the future. There are numerous works that engage with anticipatory or utopian orientation to better futures (Anderson, 2006; Harvey, 2000; Kraftl, 2007; Pinder, 2015). The risk is however that studies of urban aspirations or the culmination of imagination repeat assumptions about linear temporality, where the future remains an abstract thing toward which the present is heading. Working with the notion of promise instead, authors like Weszkalnys have paved the way for a critique of how its particular temporal mode is tolerated (or even nourished) in the capitalist project as long as it serves as a kind of "sustained pause, as long as it helps organize infrastructures in a way that eases the upwards trajectory of progress" (Weszkalnys, 2015: 632).

Urban planning and infrastructures are two particularly rich fields of study in which promises serve to reproduce the linear progressive temporalities of development and modernity (Abram and Weszkalnys, 2013; Anand et al., 2018; Hetherington, 2016). But the redemptive powers of urban promises also equip them to curtail waywardness and errancy - something that black critical thought has always reminded us as embedded in the promises of freedom or the end of racism (Carter, 2019). For if residents "do the right thing" then "things will move on", livelihoods will transition into being better. It is in this sense that promises point to the transitive, what is experienced now is only temporary; things need not be what they are, and so the future largely becomes a "corrective," still looking at the terms of the past for its incipience now.

Urban renewal and development have always speculated on the extent to which certain bodies, things, and territories could be removed, enrolled, and deployed at affordable prices. As such, in Cities of the Global South (Simone, 2014a, 2020), some districts are treated like start-ups, continuing long histories of incremental experimentation with complementary forms of entrepreneurship (Gago, 2015); others are bastions of apparent illegality that put food on the table through a host of illicit practices that generate substantive income for police and politicians (Müller and Weegels, 2020). All of these are practices of promising, practices that can constitute the underlying asset for forms of managing uncertain futures that will never belong to the residents themselves. 
Jakarta and Rio de Janeiro exemplify efforts to reframe whole poor and working-class neighborhoods as wellsprings of resilience, harbingers of new niche economies, environmental management, and appropriately scaled sustainable urban transitions (Mosciaro and Pereira, 2019; Rethel, 2018). It is from here where all kinds of "start-ups" and "financialization mechanisms" are habitually presented as the new affective machines to revive capitalism's Promise of Happiness (Ahmed, 2010) against the setbacks of economic shrinkage.

However, it is also through these processes that promises leave the realm of the probable and lead into the uncertain terrain of the possible, populated by desires, lures, attractions. Their proximity to failure, their ephemerality, opens them for all kinds of becomings, potentialities, and ordinary acts of future making. From this view, then, what has been described as "anticipatory urbanism" (Woodworth, 2018: 892; Zeiderman, 2016: 161) does much more than catapult residents into either an accelerated "time lapse" of progress and renewal or else confine them to zones of abandonment and standstill.

Instead of thinking the anticipatory tense of urban promises as a kind of impasse, where the future is always only the prolongation of the present, we draw attention to those ordinary socio-material arrangements that stand by the promise as a way of "active inactivity" (Kemmer et al., Forthcoming) and which manage to anticipate urban futures beyond the likely, the predictable, or the expectable. In other words, standing by the promise escapes the impasse of the present by producing an interruption in the allegedly linear transition of time, which, other than a mere deferral of realization evokes a range of emergent scenarios, many of which never manage to implant themselves fully, but nevertheless interrupt, redirect, and render a seeming stasis something else. These are scenarios that generate "minor" futures (Deleuze, 1986; Katz, 1996, 2017; Savransky, 2020).

Both Rio and Jakarta have become the recipients of urban promises, but each also avoids too much preoccupation with whatever has been promised. The urban collectives we write about are held together by an atmosphere of abiding both in the sense of observing how things unfold and sometimes seemingly inexplicable and sudden acts to rearrange their environments. Rather than passive recipients of failed promises, residents in our Rio de Janeiro and Jakarta neighborhoods are often prepared to experience their realization in unfamiliar forms. They stand by the specific terms in which a promise was issued, that is, they risk to be disappointed, worn out, or hurt; they attach themselves to the things promised; yet, at the same time, they manage to outlive the failures and mismatches that fill the timespace in-between the issuing of the promise and its un/fulfillment.

As researchers working with local residents' organizations, work geared toward the development of local government, and community-based infrastructural services, we have canvassed the attitudes of residents about the evolvement of living conditions in poor, working, and lower middle-class districts of urban cores in Jakarta and Rio. While Laura Kemmer (author 1) recently finished a five-year project that explores how new forms of urban collectivity emerge from the breakdown and re-installation of popular transport infrastructure in Rio de Janeiro (Kemmer, Forthcoming), AbdouMaliq Simone (author 2) has done most of his work in recent years in Jakarta, exploring where the city is "going" from its highdensity markets and mega-housing developments (Simone, 2014b). In this article, we present a sketch of how these stories might be woven within a shared program of comparative urban futures analysis (Wilkie et al., 2017). What guides our collaborative ethnographic project is an attempt to read the dispositions of ordinary neighborhoods simultaneously (Robinson, 2016) both as a matter of their historical elaboration but also as to what they might "offer" each other as ways of rethinking what might be possible in their standing by each other in the midst of what are tumultuous changes for each. 


\section{Beyond redemption: Holding on to the promise in Rio de Janeiro}

The middle name of Brazil's president is "Messias." Ever since appearing as the fresh front figure of the country's far right, Jair M Bolsonaro has lived up to this name. "God does not summon those who are capable, rather, he capacitates the chosen ones," the newly proclaimed candidate of the Social Liberal Party (PSL) announced in a public speech during the electoral campaign of 2018 (Soares et al., 2018). A few months later, Bolsonaro (2019) used his inaugural address to reaffirm his "mission" to restore the country by freeing it from "ideological chains" and has since presented various government initiatives that seek to revert the progressive politics associated with the former government of the Worker's Party (PT) - from university quota for black students over the constitutional right to the city to environmental protection mechanisms. In a certain way, Brazil's president acts against everything that theorists like Hannah Arendt have identified as necessary condition for all political virtues, that is, the capacity to make promises about the future (Arendt, 1972: 92). Rather, it seems to be the dubious virtue of the far right — not only in Brazil — to call out a novel, messianic temporality (Engström, 2014; Sprinzak, 1998). The failed promises of former governments provide the basis on which Bolsonaro and his likes build their temporality of redemption, which, unlike promises, closes down futures "as waiting for" (Poleshchuk, 2014: 60).

"There is no future if we don't share it, there are no such things as a Messiah with a weapon in his hand." ${ }^{2}$ Rio de Janeiro's champion samba school Mangueira has chosen a refrain for their 2020 carnival competition song that calls upon the city's slum dwellers to stand united against the bellicose futures foretold by the new national and city governments.

After the transitory tense of a national "Order and Progress"-promise that guided Bolsonaro's predecessors and also superseding the messianic times announced by his new government, a third way of anticipation has emerged in post-crisis Brazil, which calls into question the univocal temporalities of modern politics. In Rio, residents summarize many things that did or did not happen in the past years of financial emergency and mega-eventrelated investments with ficou na promessa - things that literally "stay in the promise."

Author 1 has overheard this expression many times in residents' conversations about the future trajectories of their central-city districts, and newspaper headlines have quoted it when reporting about the contested "renewal" of infrastructures, industries, and environments in these areas: "The expected cleanup of the highly polluted Guanabara Bay stayed only in the promise" (Nitahara, 2016); the recovery of the degraded port area for housing and business "stays in the promise which did not leave the papers" (Observatório das Metrópoles, 2017); and "for the time being, what stays in the eternal promise" is also the socio-spatial re-integration of the city through new public transport solutions (Galdo, 2019). None of these has been fulfilled, and maybe none was ever even likely to be realized. Fantasies of swimming and fishing in the bay are confined to daydreaming, the glassand-steel buildings of Porto Maravilha (Marvelous Port) remain skeletal, and the consortium that operates the new hyper-modern light rail vehicle in the center regularly threatens to suspend service if the city government does not pay back its debts from the shared investments.

However, "it stayed in the promise" is not only to express frustrated hopes for a better future, or some passive kind of waiting for salvation. It rather means that residents have not crossed these promises off that they "stand by" them and attentively follow their trajectories.

Inhabitants of Rio's central Santa Teresa district have followed the course of an abandoned tramline in their yearly march ever since a major accident in 2011 led to the 
suspension of the whole system. When the city mayor climbed up the stage a few hours later to promise a general overhaul and timely reinstallation of the transport infrastructure, residents just shrugged their shoulders and started preparing for their first "year without tramway." It is from this moment - the suspension of the last inner-city means of stateowned public transport in Rio de Janeiro-that author 1 has built her project, which inquires into how the affective bonds between residents and infrastructural materiality generate new forms of urban collectivity.

Throughout a total of five years, between 2014 and 2019, author 1 has participated in the commemoration of four, five, six, and seven years "without tramway;" she walked with protesters up and down the narrow streets, occupied stations and planted vegetables in track beds, and chased scrapped tramway trailers and wandering stop signs until the other side of Guanabara Bay. During this period, author 1 has come across a number of "promissory things" (Kemmer, 2019), which exceed human speech acts and generating unusual alliances between the bourgeois parts and the many favelas of the neighborhood.

One of these promissory things is a wooden and rubber-wheeled, "minor" version of the tramway. This vehicle has been following the course of the abandoned tramway tracks on the occasion of various years "without tramway," accompanied by local artisans and petty bourgeois artists of any political hue, pushed by members of the predominantly white middle-class association, its narrow benches occupied by Black youth from the brick-and-concrete buildings that cover the slopes of Santa Teresa hill. Today, the tram replica is parked at the crossroads between supermarket, garbage disposal, and Túlio's simple dwelling.

Túlio is a carpenter, builder of all kinds of waste-sculptures, and the author of what residents call the "tramway we want." The 58-year-old man from a poor farmer family of Minas Gerais - the neighboring state in Rio de Janeiro's northwest - came to the city in the late 1970s to look for a job and soon found himself stranded, like many others, on the Santa Teresa hill. Then and now, the neighborhood attracts people like Túlio, workers in search of new opportunities, who want to stay in the heart of the city, yet to keep it at a bearable distance. Since the 1968s, when many of those who opposed Brazil's military dictatorship found shelter in Santa Teresa's narrow streets and decaying houses, the neighborhood keeps its dubious reputation as "communist" refuge and breeding ground for all kinds of resistance. Túlio has picked up one of these resistant matters, reproducing, through his tram model, the only means of transport in Rio that never raised its ticket price.

What makes the miniature tramway a "promising thing" is well summarized in Túlio's story of how his replica filled with life: When he started building a model of the original vehicle for the first year's march along the tracks, he just thought about making it "look alike." But since his tram moved downhill, towards the urban core, "it pointed us towards the future, leading people on their struggle for public transport [transporte popular]."

Over the years, Túlio's miniature tram has become "more than a replica, rather a possibility." Leading author 1 to the inside of the wooden trailer on a foggy day in August 2018, Túlio pointed at the footboard covering the whole length of the vehicle, grasped one of the side-handles, and swung inside the carriage. During the reinstallation process, the authorities had presented an endless number of always-changing design plans, fare systems, and train schedules. Holding firm of the handle, Túlio explained that this small device enacted a different future tramway than the one presented by the transport ministry and railway company: "A vehicle that allows you to step on the footboard, and ride along for free." (cf. Kemmer, 2020) A popular means of transport for the ordinary, affordable, and accessible and serving the kind of population that still makes the majority of many central districts in cities of the Global South. Unimpressed by plans for closed carriages, 
presentations of retractable footboards, and the announcement of higher ticket prices and schedule restrictions, Túlio's mini-tram has continued its yearly journey through the neighborhood. It outlived all these projects, neither judged them as failed promises nor bought into their version of optimal neighborhood transport.

Instead of becoming stuck in some bottleneck timespace from where only public functionaries, company bosses, or professional engineers could lead them out, seemingly "minor" things like the tram replica enabled residents to prolong the anticipatory state that they have entered once the promise of a tramway-comeback was put on the table. Standing by the promise, here, was an anticipatory act that deliberately stretched the timespan between the promises' first utterance and its potential un/fulfillment into an indefinite infinity. Each time the authorities called upon selected journalists to report on a surprise revelation of a new tram model, a group of residents already stood by the veiled vehicle that had been so cautiously placed on the rails during a nighttime operation. It was as if the tram had entered a "holding station," a delay that demanded activity, and from where its future course could be anticipated into all kinds of directions.

Over the years, a specific "rite" has occupied a more or less prominent place in the program of the event that is held every year to remember the day of the tramway accident in 2011. Borrowing from a renown Afro-Brazilian ritual that involves washing the stairs of the iconic Bomfim-Church of Salvador, in Brazil's northeastern state of Bahia, a woman spilled water over the floor of an abandoned station of the Santa Teresa tramway in 2015 to "prepare it for the return of the tramway," as she explained to the people surrounding her. What is remarkable about this ritual is not only its transposition from preparing a religious building for the advent of something mystical, transcendental toward preparing for the return of a tramway, but also that at this point in time, the tramway had already resumed its journeys through the neighborhood.

In August 2018, residents have walked the tram tracks for the seventh time in a row. Fica na promessa, the tramway stays in the promise, Túlio says while he slowly pushes his "minor" version uphill. He will neither accept the reinstallation as promise fulfilled nor decide that it has been broken. In many ways, the new schedule which excludes those who need transportation before 9 am and after $4 \mathrm{pm}$, and the increased fare of $20 \mathrm{R} \$$, which now is five times higher than a bus ride, stand for the failed promises of a public means of transport. Still so, we stay with the tram's promises, Túlio affirms. While counting the years "without tramway," residents continue to hold each other on their march along the tracks, not as a desperate gesture, but as a way of holding on to the possibilities of affordable and accessible urban itineraries of movement. Standing by the promise means affirming that it is still "there" and to remind public authorities that they have not fulfilled it-yet.

\section{Let things come: Outliving the promise in Jakarta}

Similar to Rio, promises in Jakarta became something else besides lures, manipulations, or meaningless inheritances of citizenship. Through residents' own steady, incremental efforts to continuously work on their conditions, to turn them into resources, and to recalibrate relations of all kinds in face of the volatilities of the larger city, promises were induced as the by-products of district-level efforts to show their capacity to attain a measure of selfsufficiency. Of course, the Indonesian state promised and continues to promise many things. Suharto's New Order offered the compact that if urban residents would relinquish their often irreverent, play-by-your-wits mode of everyday accumulation, and rambunctious, often carnivalesque sociality, and opt for respectability and discipline, that everyone could eventually be "middle-class" (Abeyasekere,1987, Sajed, 2017). Local district life was 
replete with imposed rituals of mundane togetherness meant to divert unruly collective action into regimens of self-surveillance (Kusno, 2019). This maintained large swathes of Jakarta's neighborhoods as cheap labor in reserve largely encumbered with the responsibility of having to fend for themselves.

Still, self-sufficiency was manifested in the capacity of these neighborhoods to piece together social solidarity and livelihoods in various ways while not devolving into incessant conflict or being overwhelmed by allegedly failed promises. Promises were important less for what they offered then for a way of keeping matters open for deliberation rather than specifying a destination to which residents were committed.

In July 2016, Budi and author 2 sat on a large makeshift sofa he had constructed along the small creek that runs alongside the shack he moved into nearly 30 years ago. Author 2 had met Budi by chance the year before after Friday prayer outside a local mosque that he regularly attended. The Prumpung neighborhood where Budi resided was a warren of tiny lanes and courtyards packed with mostly two to three story self-built houses of varying legal standing and durability. It was the site of a well-known market, and given its proximity to the urban core and to several major thoroughfares, it was also packed with short-term renters as residents had subdivided their places into hundreds of boarding houses. The density was such that, with the exception of the improvised courtyards that had been designed as small communal spaces and playgrounds, the sun rarely penetrated. This lent an atmosphere of foreboding to what is otherwise highly convivial public demeanors, which in turn masked the undercurrents of all kinds of illicit economies long practiced with both a sense of community pride and dissimulation.

Author 2 asked Budi how having 30,000 new mostly young aspiring middle-class neighbors in the concrete fortifications that prop up the recently completed mega-complex of Basura city at the other side of the creek might tip the scales for him and his neighborhood. After all, particularly for the residents in the nine newly built towers overlooking this neighborhood, the visage of a serious slum could not be that reassuring. Wouldn't this development, coupled with the strategic location Prumpung assumed in the larger scheme of things, accelerate eviction, and regeneration? Wouldn't it constitute the relinquishing of the promise made to the popular masses by the early post-independence leaders to make a city worthy of their presence and aspirations (Winarso, 2011)?

Budi was not concerned by these developments, or rather was willing to consider that they could potentially intensify what attracted him to this district in the first place. He was not naïve but simply wanted to diffuse the threat that these developments may have posed. He enjoyed the open concerts and festivals held every Sunday in Basura's shopping mall; he cited the substantial increase in turnovers at the market as many Basura residents sought to escape the high prices and low quality of the Carrefour supermarket in the complex. Not so much blind to the indifference demonstrated by these developments to his existence, Budi rather chose to find ways of "writing" himself into this indifference.

This approach to "standing by" is what Budi indicated was the difference between his side of the creek and the other. He believes that his neighborhood remains full of yet to be fully disclosed resources; that for many years the neighborhood has attracted residents and small-time entrepreneurs and hustlers that simply have bided their time, but could make their skills available at any moment. Budi anticipates that new conditions will reveal new possibilities for him and his fellow residents:

Over there, they got security guards, access cards, all kinds of rules about who comes and goes, yet the entire project was built on land of uncertain legal status; they have all of this security and money, but perhaps in the long run they are no more secure than we are here. But what we have 
here, it's hard to put your finger on it exactly, so many things are pressed so tightly against each other that it is hard to tell what is what. But when you walk around, even though you know these people all your life, everyday makes them somewhat different than what they were before; somehow they may seem to be waiting for something different to happen, and the thing is that it does, maybe not in ways that you can always say clearly, but they seem to know they are touching a nerve somewhere, that something gets re-routed through this place in a way that was not intended, just like God, himself, never intended to get involved in much of the business he ended up having to deal with.

Connections are made, results are generated, but not necessarily in the formats that would confirm clear relationships or intended objectives. Yet each stands by the promise.

In other words, the whole reason for staying in Prumpung, the whole reason for the kind of economic activities and "games" that were involved with living there, and all of the brokerage, wheeling and dealing, and risk-taking, was in order to piece together an expansive space of maneuver in, access to, and engagement with the densities of intersections that seemed to inhere in urban life. Those densities were not imagined as specific destinations or trajectories of development, for in Prumpung, in many respects, the densities "came to it", ran through it as part of some larger circulatory system.

Sometimes the police had to be paid too much, sometimes floodwaters ravaged hardearned consumption, sometimes it cost too much to do things off the books than on. Life was hard-won, but there was little sentiment on the part of residents to put too much of whatever they earned into a single objective. If Prumpung was a promised land, it was not as the definitive realization of sufficiency, but rather a place on standby. Residents stood by, not as concession to some larger determinant power from whom they were awaiting final adjudication for their fate, but rather as a willingness to follow how "making ends meet" might play out as particular actors, places, practices, resources, and specializations were brought together in a disposition that might be hard to calculate in advance; a willingness to give this process its due, but to not make an inordinate commitment to it, to bail out quickly if needed.

The very acts of anticipation we described above - all of those acts of standing by, of neither giving in to watered down versions of officious promises (Jakarta) nor of giving up on them altogether (Rio) - now become the basis on which "derelict," dissolute districts might once again be deemed generative, hopeful, promising. While threats of renewal or erasure may loom, possibilities are also defined in vernaculars specific to these neighborhoods in dispositions not easily recognizable as either good or bad, sustainable or not. It is also from here where standing by urban promises becomes a way for residents to simultaneously affiliate and detach themselves from official and usually unfulfilled promises of development so as to keep open prospects for unanticipated scenarios of livelihood formation and social collaboration.

\section{Jakarta: Tactical detachments}

The maintenance of standing by promises is a means of simultaneously remaining committed to particular modes and standards of improvement in everyday lives, while simultaneously remaining detached from them and the implications of their failures as a means to engage more errant, experimental practices of building viable living environments.

If lower- and working-class districts are increasingly being canvassed for their various assets, where the collaborations, reciprocities, and complementarities are extracted as abstracted labor potentially folded into the construction of new resilient, self-managed 
governance projects, or being scared into compliance with the normative models of economic citizenship, there still remain instances where these tendencies are circumvented. Here is the ongoing presence of a rough and tumble urban politics that manages to keep openings in place that generates dispositions not easily financialized or policed. This is evident in the conversation that author 2 had with another Budi in September 2016. He had been introduced to Budi by a local "fixer" with whom he had been collaborating in a project on remaking night markets for Jakarta metropolitan government.

Author 2 sat with Budi in one of the make-shift bars/brothels that line the elevated train track just behind the Islamic University al-Aqeedah Hashemite in Matraman. Budi had run this bar for nearly 25 years and for which he provides services primarily for truckers who ply the nearby Jatinegara market and its associated gem, bird, and flower markets as well as the major pharmaceutical market at Pramuka. It was late afternoon, and it would be hours before anyone bothers to set up shop, start cooking, or lining up the beers. This strip was hidden in plain sight, barely detectable from ground level, but everyone in the surrounding neighborhoods knew that it is there.

While subject to the periodic cleanup campaign, these were merely ritualistic shakedowns. Where once the sex workers were consigned to filthy rooms in the back of the bars, they now more frequently lived in the areas underneath the rails in small but well-functioning houses that they had largely built themselves. Much of the urban fabric in this area has been reworked to accommodate big roads and large commercial buildings, but these ancient markets persist given the popularity and affordability of their products. The area has long been a breeding ground for tough operators, a reputation that goes back to the days when the Dutch attempted to pacify it as a center of enduring militancy by building their own residential compounds here.

Like the markets themselves, with their down in the dirt quality, with an infrastructure sagging and heaving from all of the weight of commerce and indifference to repair, the bars along the railway have not changed much in either physical character or modes of operation. Even as Budi pointed in every direction to the signs of encroachment, new megahousing developments, shopping malls, flyovers, and commercial buildings, he designated this area of Matraman-Jatiinegara as the "heart of the city," with its history of Arab settlements and institutions, its gang wars and army encampments, its early roll-out of middle-class living next to working-class districts who had not bothered to refurbish buildings over a century old.

Instead of talking about the ways in which residents worked together to build this area, Budi talked about the present as a never-ending anticipation of negative judgments, impulsive gestures to get rich on one shaky scheme after another-all of the local complicities with parasitical developers and politicians.

Budi said that this was never a peaceful area, particularly as the notorious Berlan gangs formed by the kids of army officials fought the kids of Shi'ite factory workers protecting their neighborhoods, who in turn fought the kids of Flores Catholic low-level police officers in Manggarai. It was never really clear what these fights were about, but Budi pointed out that they kept the blood flowing, not necessarily on the street, but in the sensibilities of residents who could never stomach Suharto's "New Order" "respectability" even though they often acted as willing henchmen for it but at the same time made the regime anxious with their capacities to hatch new rackets and populist obsessions.

All kinds of discrepant aspirations, beliefs, and ways of doing things managed to stand uneasily next to each other, replete with tensions and intolerance, but they stood next to each other, allowed to each other to exist. Budi would hear all of the stories, and for the most part, the prostitution business he helped manage was more often an excuse for 
exposure, for people from different places to loosen their tongues under the auspices of loosening their pants. It was a place no one should have been at anyway so there was nothing to lose in issuing reports from the "front."

Budi played all sides and he emphasizes that such a maneuver was more necessary now than it ever had been, otherwise, "we're going to get pushed out and this heart is going get fat." He bemoaned the current obsession with fighting for the integrity of the "faith," the tons of Gulf money floating around, and for seeing in every problem of Jakarta a conspiracy against Islam waged by the Communist cockroaches that were not put to rest in the massacres of 1965. While Budi pointed to intensifying divisions in the military that have long attempted to resolve themselves through old fashion red baiting, he also said there was a deeper anxiety among Jakartans about what it is that they are supposed to do with themselves in a city whose capacity to make things is drowning in just-in-time delivery of nearly anything. This, a process that Budi says wears away Jakarta's long-honed capacities for everyday negotiation, of figuring out the value that potential relations among livelihoods, places, and entrepreneurship could generate.

What Budi called the 17th parallel, in an ironic play with communist phobias and militarization, is that strip that runs from Jatinegara to Pramuka that is not yet "colonized" by developer's aspirations, which provide the big payoffs to the political parties. It maintains its mix of sin and mysticism, thuggery and cooperation, commerce, and popular folklore. The bars along the rails are situated so that the "management" can see what is coming from all sides, a skill that was put to use for much more than running a sex business, for from here, one can see the 17th parallel up and down, all the way from the trade in fake drugs to fake gems, with a lot of real stuff in-between.

Deep into the night, the bars, with their cheap lanterns and Dangdut music, still cater to a variety of tastes. But Budi cared less about being a barman than some kind of guerilla operative, as he huddled over maps with a coterie of young men pointing out just who should be informed that some stall owners in the bird market are being harassed by vigilantes from a distant mosque, of who in the local authority should be bribed, and how much to stop a planning application going through for a new petrol station around the corner, about which journalist should receive the cellphone-made movie of a local political hack assaulting the daughter of a friend who refused to sell his shares in an informal parking lot that the hack wanted to sell for an upscale apartment block.

Budi was not going to stand by and let all of the grandchildren of the street toughs and teachers, the dealers, and healers that made this strip be pushed from the heart of the city. De-militarized or not, for Budi, the 17th parallel was about the proximity of having many sides. This was its promise, not that one side or another was to be chosen, to represent a proper way of life. Here, there was "no reunification," no putting "everything into the same box." It is not that the "heart of the city is fixed in one spot; it's not that it can't be transplanted elsewhere in order to survive." What made this area vital cannot be insulated from the rest of the world; it must modulate its acts of anticipation, make itself available to all of the volatile rearrangements of things. Yet, Budi spoke metaphorically about the importance of detaching places like this from the prevailing mathematics of concessions, accommodations, and compensation. This was not so much detachment of a place or time, but rather how lines were drawn - not as borders, but as conduits, lines of flight, and inhabitation. "People can make what they can out of anywhere they might find themselves," he said. Rather, "this place here," again pointing the line running from Jatinegara to Pramuka, "can't endure without it." "So I take a stand."

Through a detachment from urban promises, some other kinds of possibilities for residents might ensue. Here, detachment is from the standardized versions of viability, from the 
association of promises' failure with the capacities of residents, from the sense that the spirit and capacities of social collaboration long honed in majority districts can only take place in a particular place, and at the same time, detached from the sense that wherever residents may find themselves is simply a prelude to something else, that it is something in need of development, in need of being different than what it is. Residents may still stand by and with that which is promised, that which takes place in specific territories of residence and affiliation, and with the prospects that what they have long practiced could form the basis on new livelihoods and better futures. Yet, an important aspect of their own notion of "promise" is that none of the vectors quite account for how they view their capacities and prospects. They stand by, attentive, indifferent, and detached.

\section{Rio: Purported indifference}

For those of Rio and Jakarta who have long lived with derogations of their everyday lives, maintaining ways of standing by the promise is a tactical detachment essential for reconciling relations between the reliable and the ephemeral, between strong attachments and noncommittal relations that make the fragile balance of their majority districts. Here, urban promises point to an elasticity of the relations between human/material "promisors" and residents that can be described as constitutive looseness (Stäheli, 2018). As such, "minor" futures emerge from the indeterminacy of "time buffers" or moments of temporal suspension between expectations and actions, between imagination and materialization, and between declarations and dispositions. Infrastructures, rather than functioning as "traps" in the way we have described above - promising to bring progress and better futures only to capture residents' desires and aspirations and then to immobilize them - can also enable specific "cuts" (Strathern, 2015) in the never-ending stream of relationality that seems to compose the urban and, by this, enable a movement which sets things loose in order to enable collectivities to refigure themselves, to find new ways of operating under the radar, and thus to persist.

In Santa Teresa, the same Túlio leaned out of his self-made tramway carriage: "This is how we have become exposed. To everything that might happen to the tramway, and the neighborhood." During the four years of suspension, residents had literally "stuck their necks out" while they had manifested their opinions in protest actions and negotiations with authorities. Every time they dug out another map, thought lost, of the century-old tramway system from their jealously guarded private archive and put it on the negotiation table, they showed their precious "cards" without guarantee that the authorities would give them something in return.

However, the major risk connected to such kinds of exposure during the tramway suspension, Túlio said, was that residents would be hurt, disappointed, exhausted by their faith in the comeback promises. By holding on to the promise, by acting as the addressee of the promise, by claiming its fulfillment vis-á-vis the authorities, they entered a relation of confidence, trust, or reliability that might have turned out as "too tight" because the terms upon which the promise had been issued were not at all guaranteed to be met. This kind of risky proximity, the uncertain "not yet" of urban promises, was the kind of handing yourself over that according to Túlio had made residents most vulnerable and their situation most precarious. Those were four years "at the mercy of life." While the tram stayed in the promise, the neighborhood became more and more of an "open wound." Túlio drew vivid pictures of the many construction sites which left gaping holes in the historic cobblestone pavement, opening to bowels of pipes and cables; of the frequent water spill-outs and locally infamous railway-rivers that run down the steep streets and into ground floor 
dwellings; the power blackouts and gas leakages released from Santa Teresa as if "evaporating from a sick body."

Since the tramway was back on track now, author 1 asked Túlio in 2016, who had won the tricky game of mutual anticipations? Maybe the new model was to be the "tramway we want" or at least it appeared to be similar to his miniature replica from its external appearance. But what about the new ticket fare of more than five US-Dollar (20 R\$), which cost about five times a bus ride in Rio, or the retractable footboard, which now prevented passengers from staying outside during the journey and riding the tram for free? In lieu of an answer, Túlio showed his most roughish smile. "We have attached ourselves to the promise, not to the bonde [tramway]."

His statement connected to conversations author 1 overheard around the neighborhood during that time. People were discussing desbonde or disconnection from the tramway. Túlio confirmed that indeed, the neighborhood would be able to detach from that yellow vehicle which, for now, seemed to have no future as "public" transport. Des-bonde's relation to desligar [to disconnect, to unplug] also meant that while formerly, attention [se ligar, coll.] had been intensely focused on the tramway, this attention could as well be redirected if necessary. The game of anticipating and promising had made residents see through the logic of such relations. "We need to continue struggling for what the tram could be, Túlio explained, but we need not struggle for the tram anymore."

A few days later, in April 2016, the smell of burnt plastic and gasoline led people to Santa Teresa's main street. As soon as the first pictures of a burning bus which had caused the commotion appeared on social media, a few people commented that they had mistaken it for the tramway. Indeed, the busses use some of the tramway infrastructure. Their routes follow the railway tracks, they stop at the former tram stations, they hit the same lampposts. Today's yellow mini-busses that have replaced the tramway since its suspension are at the center of all kinds of fofoca/rumors. Drivers forced to overpass speed limits, decaying vehicles, doors that fall off during the ride, stops are left out, passengers left behind, and money for maintenance disappears. It is as if the tram-infrastructure would provide a constant background noise. From time to time, single elements make themselves heard through the sound of a crash, the squeaking of worn-out axes, the chorus at a demonstration against fare-rises.

These premises of what once was the railway-promise still mobilize. But they are no longer associated with the trams. "Get lost!" was the motto of one of the biggest protests against the local bus company. On 6 March 2016, a group of around 70 people gathered on the central square of Santa Teresa. One of the first speakers to climb up the stage was Joana, a member of the "mothers of Santa Teresa." Four months prior to the event, these women had opened a WhatsApp chat under the same name to keep each other updated about "potential threats to their children" on their daily ways through the neighborhood. Joana's voice was shrill. "Four months. Four months have passed since the fatal accident," she shouted, "he was driving on the wrong lane, overtaking one, two other busses, then stopped right on the tracks at the old tram station." Mother, grandmother, baby. One after another left the bus, when it suddenly accelerated, causing the old lady to fall, baby in her arms. That is how Joana ended her story. She cried. "This was the rupture we needed. The accident with the tramway happened right here. They scrapped our tram. Now, busses are the new tragedy." The tramway resurged through her account. People on the tracks, injured, Joana crying - the audience burst into spontaneous applause.

The crowd now fell into a chorus, accompanying Claudia, a member of the neighborhood organization and co-organizer of the event, together with the "mothers": "Driver, watch the street, that lamppost is not made of rubber, it's made of steel. This is not right; this is my 
right. I am passenger, I demand respect." Receiving recognition as passengers also means acknowledging that transport is public. Everyone should be able to use it, from young to old, the poor, the slow ones. What is more, claiming your right as passenger makes you part of a wider collective. "This is not happening only here," João, a speaker from Rio's Free Fare Movement declared. "Other neighborhoods are mobilizing. The new rapid transit busses reinforce social apartheid. They separate the Western and Northern areas [mainly covered by favelas] the Southern Areas [Copacabana and Ipanema]." Since residents started attacking the local bus company, they have received attention and support from groups that did not appear at tram-protests before. While the tramway is seen as a unique feature of Santa Teresa, as part of its cobblestone charm and fresh air retreat offer, the busses belong to the whole city.

In Santa Teresa, promises act as "affective bonds" (Berlant, 2007: 282) that allow for residents to keep their connections to each other and other things in the city-and at the same time not to keep them too tight. They do not attempt to stop construction works, they will not reveal too much of their attachments to any of the things promised, and they will be prudent not to become disappointed by their failures. While they attentively witness the reinstallation process, residents organize protests against the local bus company, fill up construction sites with community gardens, and hold a position of "maybe so" against the volatile classifications of the neighborhood as either dangerous favela or thriving bohème district.

What we propose in this article is that by working with the concept of standby, we can understand promises not as depending on their un/fulfillment, but rather as a modality inbetween activity and inactivity that allows for residents to maintain the constitutive looseness of urban promises as a "minor mode" of fleeting from tense attention to purported indifference. In Santa Teresa, residents have passed on-consider that the Latin promittere means "to send or put forth, let go forward"-the promises of affordable and equal access to the city from the tramway to the busses, thus making the future of their neighborhood into concrete objects and minor vehicles of the here and now.

\section{Conclusion: Standing by amidst transitivity}

Urban promises rely on the transitive, the prospect of going from here to there, essentially saying that what lies in the future is a much more generative realization of what we wanted all along. In this "conversation" between Rio and Jakarta, we have seen that residents manage to not be swept away by urban transitivity. In the particular ways in which majority districts not only piece together built environments and livelihoods, but figure affective sensibilities as well as strategic orientations towards collective life, the futures of each city become possible futures for each other. Not in terms of the specific contents of their relative "destinations" but the simultaneity of the contrasting but equally viable ways in which residents demonstrate a "life worth living."

What if the coming together of residents and things that constitute a place is itself a promise sufficient to hold them in a continuous relationship to each other, to be indifferent to assessing where they are now in terms of either where they have been or where they are going. In "What Is a Minor Literature?," Deleuze (1986) exhorts people to become minor in exactly that way, to not get carried away by the normal as the only guiding light and rather dig a hole in what passes for the normal sense of things.

Here, we have emphasized "standing by" as the ability to persist with ways of doing things that may seem of little use, that seem to have no future, but which, nevertheless, in their detachment from an apparent ecology of useful relations circumvent, for now, the tendency to evict any 
traces of "the majority" (the poor, working, and lower middle classes) from the heart of the city. Budi's position along the creeks, the following of the bonde/the tramway along the tracks - this capacity to stand by those elements of the city deemed of little value or propriety, as such, is available for remaking of all kinds. It is an insistence to be part of the "neighborhood" of any transformation, whatever comes about. For after all, the Budis and bondes are in some way fundamentally detached from any promise and therefore able to stand by them.

In the four situations we have sketched here, the "premises" of a promise do not precede it. Rather, residents have been directed toward the things that they expected would live up to the promise once they get there, be it a popular means of transport, be it the heart of the city. As Berlant (2011) indicates, attachments to promises of a better future can become "cruel" when residents hold on to them too tight even after they have become disappointed and hurt because the continuity of the form of such bond assures them that they will outlive their harmful effects, that there is some sense in keeping on struggling, hatching, and tinkering.

However, what we have shown here is that faith in the promise; running the risk to be disappointed or worn out by the promise; caring for the constitutive looseness of the promise; that all these kinds of exposure to the promise also mean that tongues will loosen, that things will lie more openly on the table, become visible, manageable. By partaking in speculations about the things to come, residents of Rio de Janeiro and Jakarta have also managed to recognize the form of their attachment, thus setting the conditions to loosen this bond (Ahmed, 2010: 28). Detachment, here, is a way of acting out a form of purported indifference, which in turn functions as a tactical maneuver to prompt other, more powerful actors, to show their cards and vulnerabilities.

In this sense, standing by the promise generates a life that cannot be considered precarious; even when it affixes itself to sentiments and expectations that clearly would seem to induce precarity, for it remains able to detach from their transitivity. With this paper, we encourage more research on how failed promises live on and which acts of anticipation they generate. Cities function like promising machines, they give everyday life a rhythm, but as they constantly fail, they prompt residents to stand by and thus allow for other prospects, other "minor" futures to pop up amidst and potentially disrupt urban trajectories of the transitory.

\section{Declaration of conflicting interests}

The author(s) declared no potential conflicts of interest with respect to the research, authorship, and/ or publication of this article.

\section{Funding}

The author(s) received no financial support for the research, authorship, and/or publication of this article.

\section{ORCID iD}

Laura Kemmer (D) https://orcid.org/0000-0003-4141-9169

\section{Note}

1. Available at: www.mangueira.com.br/carnaval-2020/sambaenredo (accessed 5 February 2020).

\section{References}

Abeyasekere S (1987) Jakarta: A History. Singapore: Oxford University Press. 
Abram A and Weszkalnys G (2013) Elusive Promises. Planning in the Contemporary World. New York: Berghahn.

Anand N, Gupta A and Appel H (2018) The Promise of Infrastructure. Durham: Duke University Press.

Anderson B (2006) Transcending without transcendence: Utopianism and an ethos of hope. Antipode 38: $691-710$.

Arendt H (1972) Civil disobedience. In: Crises of the Republic. San Diego, CA: Harcourt Brace, pp.49-103.

Berlant L (2006) Cruel optimism. Differences 17(5): 20-36.

Berlant L (2007) Nearly Utopian, nearly normal: Post-Fordist affect in La Promesse and Rosetta. Public Culture 19(2): 273-301.

Berlant L (2011) Cruel Optimism. Durham: Duke University Press.

Bolsonaro J (2019) Discurso do Presidente da República, Jair Bolsonaro, durante Cerimônia de Posse no Congresso Nacional. Available at: https://bit.ly/2KoOhIn (accessed 1 January 2019).

Carter JK (2019) Black malpractice (a poetics of the sacred). Social Text 37(2): 67-107.

Deleuze G (1986) Kafka: Toward a Minor Literature. vol. 30. Minneapolis, MN: University of Minnesota Press.

Deleuze G and Guattari F (1977 [1972) Anti-Oedipus: Capitalism and Schizophrenia, Hurley R, Seem $\mathrm{M}$ and Lane L (trans). New York: Penguin.

Engström M (2014 ) Contemporary Russian messianism and new Russian foreign policy. Contemporary Security Policy 35(3): 356-379.

Färber A (2019) How does ANT help us to rethink the city and its promises? In: Blok A, Farías I, and Roberts C (eds) A Routledge Companion to Actor-Network Theory. Oxon: Routledge, pp.264-272.

Gago V (2015) Financialization of popular life and the extractive operations of capital: A perspective from Argentina. South Atlantic Quarterly 114: 11-28.

Galdo R (2019) VLT do Rio pode parar de circular. O Globo, 21 March. Available at: https://glo.bo/ 2SQcFXY (accessed 23 December 2020).

Harvey D (2000) Spaces of Hope. Edinburgh: Edinburgh University Press.

Hetherington K (2016) Surveying the future perfect: Anthropology, development and the promise of infrastructure. In: Harvey P, Jensen CB and Morita A (eds) Infrastructures and Social Complexity: A Companion. London: Routledge, pp.40-50.

Katz C (1996) Towards minor theory. Environment and Planning D: Society and Space 14(4): 487-499.

Katz C (2017) Revisiting minor theory. Environment and Planning D: Society and Space 35(4): 596-599.

Kemmer L (2019) Promissory things: How affective bonds stretch along a tramline. Distinktion: Journal of Social Theory 20(1): 58-76.

Kemmer L (2020) Free riding Rio: Protest, public transport and the politics of a footboard. City \& Society 32(1): 157-181.

Kemmer L (Forthcoming) Bonding. Infrastructure, Affect, and the Emergence of Urban Collectivity. Oxford: Berghahn Books.

Kemmer L, Kühn A, Otto B, Weber V (eds, Forthcoming) Organizing modes of in/activity (special issue). Ephemera: Theory and Politics in Organization.

Kusno A (2019) Middling urbanism: The megacity and the kampung. Urban Geography 41(7): 954-970.

Kraftl P (2007) Utopia, performativity, and the unhomely. Environment and Planning D: Society and Space 25(1): 120-143.

Mosciaro M and Pereira A (2019) Reinforcing uneven development: The financialization of Brazilian urban redevelopment projects. Urban Studies 56(10): 2160-2178.

Müller F and Weegels J (2020) ILLICITIES: City-Making and Organized Crime. Center for Urban Studies, University of Amsterdam. Available at: https://urbanstudies.uva.nl/content/blog-series/ illicities-blog-series-introduction.html?origin $=$ RkIy9bW8Q4G0e $\% 2 \mathrm{FaGMRg} \% 2 \mathrm{FOA} \& \mathrm{cb}$ (accessed 23 December 2020). 
Nitahara A (2016) A esperada despoluição da Baía de Guanabara ficou só na promessa Agência Brasil, 8 August. Available at: https://bit.ly/3pjoxQJ (accessed 23 December 2020).

Observatório das Metrópoles (2017) Porto Maravilha. Blog entry. 8 August. Available at: https://bit. ly/2uOrRN9 (accessed 23 December 2020).

Pinder D (2005) Visions of the City: Utopianism, Power and Politics in Twentieth Century Urbanism. Edinburgh: Edinburgh University Press.

Poleshchuk I (2014) The ethics of futurity: Messianism and intersubjectivity. International Journal of Humanities and Social Sciences 4(5): 56-66.

Rethel L (2018) Capital market development in Southeast Asia: From speculative crisis to spectacles of financialization. Economic Anthropology 5(2): 185-197.

Robinson J (2016) Comparative urbanism: New geographies and cultures of theorizing the urban. International Journal of Urban and Regional Research 40(1): 187-199.

Sajed A (2017) Peripheral modernity and anti-colonial nationalism in Java: Economies of race and gender in the constitution of the Indonesian national teleology. Third World Quarterly 38(2): 505-523.

Savransky M (2020) After progress: Notes for an ecology of perhaps. Ephemera: Theory \& Politics in Organization. Epub ahead of print 4 February 2020.

Simone A (2014a) The missing people: Reflections on an urban majority in cities of the south. In: Parnell S and Oldfield S (eds) The Routledge Handbook on Cities of the Global South. London and New York: Routledge, pp.322-337.

Simone A (2014b) Jakarta: Drawing the City Near. Minneapolis MN: University of Minnesota Press. Simone A (2020) Cities of the global south. Annual Review of Sociology 46: 603-622.

Soares J, Grillo M and Sassine V (2018) Bolsonaro diz que não será o 'salvador da pátria', mas fala em 'missão' e 'ser escolhido'. O Globo, 22 July. Available at: https://glo.bo/2O9F1Jx (accessed 23 December 2020).

Sprinzak E (1998) Extremism and violence in Israel: The crisis of messianic politics. The Annals of the American Academy of Political and Social Science 555(1): 114-126.

Stäheli U (2018) The mediality of looseness. Cybernetics and Human Knowing 25(4): 15-24.

Strathern M (2015) Detaching and situating knowledge. In: Candea M, Cook J and Trundle C (eds) Detachment: Essays on the Limits of Relational Thinking. Manchester: Manchester University Press, pp. 256-265.

Weszkalnys G (2015) Geology, potentiality, speculation: On the indeterminacy of first oil. Cultural Anthropology 30(4): 611-639.

Wilkie A, Savransky M and Rosengarten M (2017) Speculative Research: The Lure of Possible Futures. Abingdon, Oxon, NY: Routledge.

Winarso H (2011) Urban dualism in the Jakarta metropolitan area. In: Sorensen A and Okata J (eds) Megacities. Library for Sustainable Urban Regeneration. vol. 10. Tokyo: Springer, pp.163-191.

Woodworth MD (2018) Landscape and the cultural politics of China's anticipatory urbanism. Landscape Research 43(7): 891-905.

Zeiderman A (2016) Endangered City: The Politics of Security and Risk in Bogotá. Durham: Duke University Press.

Laura Kemmer is a postdoctoral researcher at the department for Human Geography, Humboldt-Universität zu Berlin, working on urban transitions, more-than-human temporalities, and cities "after redemption." Her PhD research involved extensive ethnographic fieldwork in inner-city Rio de Janeiro combined with reflections on urban promises, failed infrastructures, and loose bonds. This article is closely linked to a special issue project on "standby" with Annika Kühn, Birke Otto, and Vanessa Weber, forthcoming with ephemera journal. 
AbdouMaliq Simone is senior professorial fellow, Urban Institute, University of Sheffield and Honorary Professor, African Centre for Cities, University of Cape Town. He writes widely on issues of global urbanism, popular economies, urban racialism, and Islamic political practice. Most recently, author of Improvised Lives: Rhythms of Endurance in an Urban South, Polity Press (2019). 